\section{Less mercury?}

SIR - Camargo ${ }^{1}$ dismisses Nriagu's ${ }^{2}$ assertion that mercury emissions from precious-metal refining in the early New World may have an impact on the presentday global mercury cycle. Unfortunately, Camarago's argument is undermined by the use of outdated, poor-quality data collected before people became aware of the need for ultra-clean sample-handling protocols $^{3-5}$.

Camarago, for example, cites a 15-yearold EPA report ${ }^{6}$, founded on much earlier data, for his assertion that the total natural-source atmospheric $\mathrm{Hg}$ emission budget is $25-50 \times 10^{9} \mathrm{~g} \mathrm{yr}^{-1}$. But it is now generally accepted that the total gobal atmospheric emission budget is about 6 $7.5 \times 10^{9} \mathrm{~g} / \mathrm{yr}^{-1}$, with approximately 30 . $75 \%$ of that as natural emissions, and perhaps as much as $20-30 \%$ due to fossil fuel combustion ${ }^{7-11}$. Using these values results in more refined estimates of the atmospheric residence time for $\mathrm{Hg}$ of $0.5-2$ yr (refs. $7,8,10$ ).

Camargo also overestimates the potential pool of $\mathrm{Hg}$ contained in the oceans by two orders of magnitude, choosing very old and discredited values as representative of the world oceans ${ }^{12,13}$. Using ultraclean techniques many researchers have now confirmed that ocean water, even near the shore, contains approximately $0.5-1 \mathrm{ng}^{-1} \mathrm{Hg}$ (refs $4,7,14$ ), resulting in an estimated $10^{12} \mathrm{~g} \mathrm{Hg}$ residing there at any one time. From this, we can calculate a mean oceanic residence time for $\mathrm{Hg}$ of approximately $350 \mathrm{yr}$, which is comparable with other particle-reactive metals in the sea ${ }^{15}$. This implies that much of the $\mathrm{Hg}$ emitted over the past 500 years still resides in the ocean, where it may be available for methylation, biological uptake, revolatilization, and recycling to the atmos-

1. Camargo, J. A. Nature $\mathbf{3 6 5}, 302$ (1993)

2. Nriagu, J. O. Nature 363, 589 (1993).

3. Patterson, C. C. \& Seattle, D. in Accuracy in Trace Analysis: Sampling, Sample Handling, and Analysis (ed. Lafleur, P. D.) 267-275 (NBS SP-422, Washington, DC. 1976).

4. Gill, G. A. \& Fitzgerald, W. F. Deep-Sea Res. 32 287-297 (1985).

5. Fitzgerald,W. F. \&Watras, C. J. Sci. tot. Envir. $\mathbf{8 7 / 8 8}$ $223-232$ (1989).

6. US Environmental Protection Agency Ambient Water Quality Criteria for Mercury (EPA, Washington, DC. 1980)

7. Fitzgerald, W. F. in The Role of Air-Sea Exchange in Geochemical Cycling (ed. Buat-Menard, P.) 363-408 (Reidel, Dordrecht, 1986)

8. Slemr, F. et al. J.atmos. Chem 3, 407-434 (1985)

9. Nriagu, J. 0.\& Pacyna, J. M. Nature 333, 134-139 (1988)

10. Lindqvist, O. etal. Wat. Air \& Soil Pollut. 55, 1-261 (1991)

11. Porcella, D. B. in Mercuryas a Global Pollutant (eds Watras, C. J. \& Huckabee, J.W.) (in the press).

12. Hammond, A. L. Science 171, 788-789 (1971).

13. OCED Mercury and the Environment (OCED, Paris, 1974)

14. Bloom, N. S. \& Crecelius, E. A. Mar. Chem. 14, 49-59 (1983)

15. Broeker, W. S. \& Peng, T. H. Tracers in the Sea 26-27 (Eldigo, New York, 1982)

16. Fitzgerald, W. F. et al. Science 224, 597-599 (1983)

17. Hoffman, R. J. et al. USGS Water Resources Invest. (USGS Report 89-4105, 1990).

18. Nriagu, J. O. Sci. tot. Envir. (in the press). phere $^{7,16}$. Thus, modern and past anthropogenic emissions contribute to an increased global 'background' $\mathrm{Hg}$ concentration.

The degree to which the early emissions discussed by Nriagu affect the current budget is difficult to judge because of the incomplete summation of all $\mathrm{Hg}$ emissions from that time to the present, and our lack of knowledge as to the degree which $\mathrm{Hg}$ stored in deep ocean water is biogeochemically active and available for eventual revolatilization to the atmosphere. For example, it has recently been estimated that $6 \times 10^{10} \mathrm{~g} \mathrm{Hg}$ entered the environment in the nineteenth century via the recovery of gold and silver during the North American gold rush ${ }^{17,18}$. But without a quantitative estimate for the summation of all releases during this interval it is impossible to compare its impact relative to the earlier and later South American gold rushes.

\section{Nicolas S. Bloom}

Frontier Geosciences

414 Pontius Ave. N, Suite B,

Seattle, Washington 98103, USA

Donald B. Porcella

Electric Power Research Institute,

Palo Alto, California 94303, USA

\section{Can diamonds be dead bacteria?}

SIR - The reports by Lilley et al. ${ }^{1}$ of isotopically very light carbon in methane from an unsedimented mid-ocean ridge system, and by Schrauder and Navon ${ }^{2}$ of the discovery of solid $\mathrm{CO}_{2}$ in diamond, reinvigorate an interesting question. Although Lilley et al. conclude that sediments from turbidites were a more likely source of methane and ammonia, their report raises the question of the long-term future of organic vent communities on unsedimented ridges, destined for eventual subduction. Are eclogitic diamonds fossils? Are they derived from metamorphosed clumps of carbon that originated as bacteria from ancient mid-ocean ridge hydrothermal systems?

The possible organic origin of some diamonds has been pointed out by Kirkley and Gurney ${ }^{3}$. To date, much of the discussion has centred around the possibility that organic material from sediments may have supplied the carbon. However, Deines et al $^{4}$, studying websteritic-type diamonds, discounted an organicsediment origin for the isotopically light carbon on the grounds that a subduction hypothesis would demand an extreme ophiolite differentiate to explain the iron and chromium contents. Such differentiates are unlikely in association with sediments, but are expected near ridge hydrothermal communities.

The case for an organic origin rests essentially on the isotope composition of the carbon in the diamonds occurring in eclogites, which commonly ranges from $\delta^{13} \mathrm{C}$ of $0 \%$ to as light as $-25 \%$, and in rare examples yet lighter, to $-35 \%$. The main source of carbon as light as this is organic. Bacteria show a wide range of carbon isotope compositions. Isotope fractionation in the Rubisco pathway is about $-29 \%$, which with tre chemical fractionation between dissolved $\mathrm{CO}_{2}$ and carbonate (about 11\%o) allows a maximum biological fractionation of about $-40 \%$. Perhaps more relevant to the proposed hydrothermal setting is that archaea (such as methanogens) can range further, to extremely light $\delta^{13} \mathrm{C}$. Further, the sulphur isotope ratios of many sulphide inclusions in eclogitic diamonds suggests a biogenic origin ${ }^{5}$ and the high manganese content of some diamondiferous eclogites and eclogitic inclusions in diamonds ${ }^{6}$ is not inconsistent with a hydrothermal source.

Late Archaean and Proterozoic oceanic crust would have contained a thick mafic upper layer, with vigorous hydrothermal circulation. Abundant vent communities may have existed, becoming incorporated into an altered carbonate-rich lava pile and eventually subducted. It is then logical to ask what happened to the bacterial communities that are widely assumed to have been present on Archaean and Proterozoic mid-ocean ridge hydrothermal systems? A possible answer is that some diamonds derived their carbon from bacterial communities, either directly from reduced organic carbon via graphite, or indirectly via a locally generated gas phase that incorporated both very light organic-derived carbon and also $\mathrm{CO}_{2}$ from carbonate. The original organic carbon may have been in the range -30 to $-50 \%$ o. Metamorphism tends to shift organic carbon to heavier isotope ratios. The present isotope content of the diamonds would range from near-organic ratios $(-35 \%)$ to more common heavier compositions (0 to $-25 \%$ ) that reflect varying degrees of metamorphism and exchange with country rock carbon from carbonate. There are probably many origins of the carbon in the various types of diamonds, but it is possible that a few diamonds are indeed our ancestral relics.

E. G. Nisbet

D. P. Mattey

D. Lowry

Department of Geology,

Royal Holloway College,

University of London,

Egham, Surrey TW2O OEX, UK

1. Lilley, M. D. et al. Nature 364, 45-47 (1993)

2. Schrauder, M. \& Navon, O. Nature 365, 42-44 (1993).

3. Kirkley, M. B. \& Gurney, J. J. Abstr. 28th int. Geol. Congr Diamond Workshop $\mathbf{4 0}$ (1989).

4. Deines, P. et al. Geochim. cosmochim. Acta. 57, 2781 2796 (1993).

5. Eldridge, C. S. et al. Nature 353,649653 (1991)

6. Deines, P. et al Geochim cosmochim. Acta. 51, 1227 1243(1987) 